\title{
Review Article \\ Regulation of Adherens Junction Dynamics by Phosphorylation Switches
}

\author{
Cristina Bertocchi, ${ }^{1}$ Megha Vaman Rao, ${ }^{1}$ and Ronen Zaidel-Bar ${ }^{1,2}$ \\ ${ }^{1}$ Mechanobiology Institute Singapore, National University of Singapore, Singapore 117411 \\ ${ }^{2}$ Department of Bioengineering, Faculty of Engineering, National University of Singapore, Singapore 119077
}

Correspondence should be addressed to Ronen Zaidel-Bar, biezbr@nus.edu.sg

Received 5 March 2012; Revised 21 May 2012; Accepted 22 May 2012

Academic Editor: Donna Webb

Copyright ( $\odot 2012$ Cristina Bertocchi et al. This is an open access article distributed under the Creative Commons Attribution License, which permits unrestricted use, distribution, and reproduction in any medium, provided the original work is properly cited.

\begin{abstract}
Adherens junctions connect the actin cytoskeleton of neighboring cells through transmembrane cadherin receptors and a network of adaptor proteins. The interactions between these adaptors and cadherin as well as the activity of actin regulators localized to adherens junctions are tightly controlled to facilitate cell junction assembly or disassembly in response to changes in external or internal forces and/or signaling. Phosphorylation of tyrosine, serine, or threonine residues acts as a switch on the majority of adherens junction proteins, turning "on" or "off” their interactions with other proteins and/or their enzymatic activity. Here, we provide an overview of the kinases and phosphatases regulating phosphorylation of adherens junction proteins and bring examples of phosphorylation events leading to the assembly or disassembly of adherens junctions, highlighting the important role of phosphorylation switches in regulating their dynamics.
\end{abstract}

\section{Introduction}

Adherens junctions (AJs) are cell-cell adhesion sites where calcium-dependent cadherin receptors bind with their extracellular domains to cadherins on opposing cells and with their cytoplasmic tails connect-via adaptors-to filamentous actin $[1,2]$. By essentially providing a physical link between the actin cytoskeleton of neighboring cells AJs facilitate the integration of individual cells into a tissue. Additionally, AJs are instrumental in setting up and maintaining the apicobasal polarity of epithelial cells $[3,4]$, they function as mechanosensors [5] and serve as a nexus for signaling affecting important cell decisions, such as survival and differentiation [6].

During the development and lifetime of an organism, cells frequently change shape and position relative to their neighbors. Hence, the ability of cells to regulate their adhesive interactions plays a key role during tissue morphogenesis, repair, and renewal $[3,7,8]$. Defects in the adhesive characteristics of epithelial cells are pathological signs and loss of cell-cell adhesion can generate dedifferentiation and invasiveness of human carcinoma cells [9]. Thus, there is great interest in understanding the factors that affect assembly and disassembly of cell-cell adhesion at the molecular level.

When considering regulatory mechanisms controlling AJ proteins, we distinguish between three subsequent steps of regulation: synthesis, localization, and activation. First, a cell controls whether proteins are synthesized or not. Indeed, transcriptional regulation of E-cadherin, notably by the snail transcription factor, plays an important role in the breaking down of AJs accompanying epithelial to mesenchymal transition [10]. Once a protein is expressed the cell can determine its localization by controlling its transport. In fact, both exocytosis and endocytosis of Ecadherin are tightly controlled and the balance between the two processes has been shown to regulate AJ turnover both in vitro and in vivo [6]. Finally, a cell can control the activity and interactions of a protein at a given location by posttranslational modifications. These modifications include glycosylation, lipidation, ubiquitination, acetylation, proteolysis, and phosphorylation [11]. Phosphorylation of tyrosine $(\mathrm{Y})$, serine $(\mathrm{S})$, or threonine $(\mathrm{T})$ residues, the topic of this review, is a rapid and reversible form of 
regulation affecting the majority of AJ proteins [12-16]. In some cases, posttranslational modifications have secondary effects on transcription and/or protein transport $[17,18]$. However, here we will focus on the more direct mechanisms in which AJs are regulated by phosphorylation. First, we will introduce the enzymes responsible for phosphorylation and dephosphorylation at AJs and discuss how they are recruited into AJ and activated. Next, we will describe the targets of phosphorylation within AJ and by examining the consequences of specific phosphorylation events will show how phosphorylation is involved both in assembly and disassembly of AJ, essentially driving the dynamics of this highly responsive structure. In the end, we will point out open questions and suggest methods to address them.

\section{Recruitment of Protein Kinases and Phosphatases into AJ}

So far, twelve S/T kinases and one S/T phosphatase have been implicated in regulating phosphorylation of AJ proteins, and they are all cytoplasmic (Table 1). Prominent kinases in this group include PKC- $\alpha$, cAMP-dependent protein kinase, Casein Kinase 1, Pak1, and ROCK1. Nine tyrosine kinases and twelve tyrosine phosphatases have been shown to be active in AJ, roughly half of them cytoplasmic and half part of a transmembrane receptor (Table 1). Prominent tyrosine kinases include the cytoplasmic Src, Fyn, Fer, and Abl, and the receptors of epidermal and hepatocyte growth factors. Major phosphatases involved are the cytoplasmic PTP1B, PTP-PEST, SHP-1, SHP-2, and receptor-type tyrosineprotein phosphatases $\mathrm{Mu}, \mathrm{U}$, and Kappa.

Some of these kinases and phosphatases have been localized to AJ by immunofluorescence (e.g., [19-21]) and others have been shown to associate with AJ by coimmunoprecipitation (e.g., [21-23]), but the exact mechanism of recruitment into AJ of most of them is largely unknown. A few were shown to bind directly with cadherin, such as CSK with VE-cadherin and PTP-1B with E- and N-cadherin $[19,24,25]$; others bind one of the catenins (adaptor proteins linking cadherin with actin), such as MET and PTPRF with $\beta$-catenin $[26,27]$ and ROCK1 with p120-catenin [21]; some interact with other AJ adaptor proteins, such as PRKCA with vinculin and ROCK1 with Shroom3 [28, 29].

While it is most likely every kinase and phosphatase can recognize at least one docking site within the AJ, it is not currently known which of the kinases and phosphatases reside in AJ permanently and which are transient components, homing in to phosphorylate or dephosphorylate AJ proteins only under specific conditions. Even permanent residents may not always be active, as most kinases and phosphatases need themselves to be activated.

\section{Activation of Kinases and Phosphatases in AJ}

Receptor tyrosine kinases are commonly activated by an external ligand, such as a growth factor or cytokine, which induces dimerization, cis-phosphorylation or autophosphorylation and activation of the catalytic domain
$[124,125]$. Receptor tyrosine phosphatases may be activated by homophilic association with their counterparts on neighboring cells [126], as well as by tyrosine phosphorylation [127]. Several S/T kinases are activated by binding of Rho GTPases, for example ROCK1 is activated by RhoA and PAK1 is activated by Racl and Cdc42 [128, 129]. $\mathrm{S} / \mathrm{T}$ kinases are also regulated by tyrosine phosphorylation and tyrosine kinases and phosphatases are regulated by $\mathrm{S} / \mathrm{T}$ phosphorylation, in a complex web of feedback and feedforward loops that is poorly understood (Figure 1). For example, Src phosphorylates PRKCD, which phosphorylates PTPN6, which in turn dephosphorylates SRC (feedback) [130-132]; PRKACA phosphorylates Src and Csk, and Csk also phosphorylates Src (feedforward) [133-135].

As will be discussed further below, some of the phosphorylation events serve to activate the kinases or phosphatases and others are inhibitory. One well-understood example of kinase activation is the mechanism of activation of Src. As reviewed in [136], the family of Src tyrosine kinases can be found in a nonactive "closed" conformation or in an "open" active conformation, depending on the phosphorylation status of a tyrosine residue at the C-terminus. When this residue is phosphorylated, it interacts with an $\mathrm{SH} 2$ domain in the middle of Src, blocking the catalytic site. Upon dephosphorylation of this specific tyrosine, the $\mathrm{SH} 2$ domain is released, and the protein unfolds, allowing autophosphorylation of another tyrosine residue situated within the enzyme's activation loop, rendering the kinase fully active [137]. It is important to point out that cadherin ligation and clustering may act as an activation signal for some kinases. Most notably, Src and Fer have been shown to be recruited to the membrane upon cadherin binding [138, 139], and EGFR signaling was shown to be stimulated by AJ formation independently of EGF ligand [140]. Furthermore, cadherin clustering has been found to indirectly induce activation of Rho GTPases [141], which in turn could activate S/T kinases.

\section{Phosphorylation Targets within the AJ}

The AJ can conceptually be divided into four layers (Table 2). The first, in the plane of the membrane, is where cadherins and other transmembrane proteins, such as nectin and AJAP1, reside. The next layer consists of membrane-bound adaptors, such as ERM proteins and MAGI1, and adaptors that directly bind transmembrane proteins, such as p120and $\beta$-catenin (bind cadherin) and afadin (binds nectin). The following layer is composed of adaptor proteins, such as $\alpha$-catenin and vinculin, which bind to the second layer adaptors and also bind F-actin. F-actin, along with actinbinding proteins, such as $\alpha$-actinin, and actin regulators, such as cortactin, would be considered the last layer. Regulatory proteins, such as GAPs, GEFs, and GTPases, can be found throughout the AJ as reviewed in [14, 142].

There is evidence demonstrating both $\mathrm{Y}$ and S/T phosphorylation of proteins in all layers of the AJ (Table 2). As illustrated in Figure 1, often the same kinase will phosphorylate proteins from different layers. For example, Abl 
TABLE 1: Kinases and phosphatases regulating phosphorylation of AJ proteins.

\begin{tabular}{|c|c|c|c|c|}
\hline Gene symbol & Protein name & Phosphorylation type & Localization & Reference \\
\hline \multicolumn{5}{|c|}{ Kinases } \\
\hline SRC & $\begin{array}{l}\text { Proto-oncogene tyrosine- } \\
\text { protein kinase Src }\end{array}$ & Tyr & nonreceptor & {$[23,30,31]$} \\
\hline CSK & c-src tyrosine kinase & Tyr & nonreceptor & {$[24,32,33]$} \\
\hline FYN & Tyrosine-protein kinase Fyn & Tyr & nonreceptor & [34-36] \\
\hline ABL1 & Abl1 & Tyr & nonreceptor & {$[37,38]$} \\
\hline SYK & Tyrosine protein kinase SYK & Tyr & nonreceptor & {$[39,40]$} \\
\hline PTK2B & Protein-tyrosine kinase 2-beta & Tyr & nonreceptor & {$[41-43]$} \\
\hline FER & Tyrosine-protein kinase Fer & Tyr & nonreceptor & {$[44]$} \\
\hline EGFR & Epidermal growth factor receptor & Tyr & Receptor & {$[45]$} \\
\hline cMET/HGF & Hepatocyte growth factor receptor & Tyr & Receptor & {$[46]$} \\
\hline PRKCA & Protein kinase C alpha type & Ser/Thr & nonreceptor & {$[47]$} \\
\hline PRKACA & $\begin{array}{l}\text { cAMP-dependent protein } \\
\text { Kinase catalytic subunit alpha }\end{array}$ & Ser/Thr & nonreceptor & {$[48,49]$} \\
\hline ROCK1 & $\begin{array}{l}\text { Rho-associated, coiled-coil } \\
\text { containing protein kinase } 1\end{array}$ & Ser/Thr & nonreceptor & {$[50]$} \\
\hline PRKCD & Protein kinase $\mathrm{C}$ delta type & Ser/Thr & nonreceptor & {$[51,52]$} \\
\hline CSNK1E & Casein kinase I isoform epsilon & Ser/Thr & nonreceptor & [53] \\
\hline CSNK2A1 & Casein kinase 2 & Ser/Thr & nonreceptor & {$[54]$} \\
\hline PAK1 & Serine/threonine-protein kinase PAK 1 & Ser/Thr & nonreceptor & {$[55-57]$} \\
\hline MAPK8 & JNK & Ser/Thr & nonreceptor & {$[58]$} \\
\hline PRKD1 & Protein kinase D1 & Ser/Thr & nonreceptor & {$[59]$} \\
\hline PRKCI & Atypical protein kinase C-lambda/iota & Ser/Thr & nonreceptor & {$[60]$} \\
\hline PRKCZ & Protein kinase $\mathrm{C}$ zeta type & Ser/Thr & nonreceptor & {$[60]$} \\
\hline MARK2 & $\begin{array}{l}\text { MAP/microtubule affinity- } \\
\text { Regulating kinase 2, Par-1 }\end{array}$ & Ser/Thr & nonreceptor & [61] \\
\hline \multicolumn{5}{|c|}{ Phosphatases } \\
\hline PTPN1 & $\begin{array}{c}\text { Tyrosine-protein phosphatase non } \\
\text { receptor type } 1, \mathrm{PTP} 1 \mathrm{~B}\end{array}$ & Tyr & nonreceptor & {$[19,62-64]$} \\
\hline PTPN6 & $\begin{array}{l}\text { Tyrosine-protein phosphatase non } \\
\text { receptor type } 6, \text { SHP } 1\end{array}$ & Tyr & nonreceptor & {$[65]$} \\
\hline PTPN11 & $\begin{array}{l}\text { Tyrosine-protein phosphatase non- } \\
\text { receptor type } 11, \mathrm{SHP} 2\end{array}$ & Tyr & nonreceptor & {$[66]$} \\
\hline PTPN12 & $\begin{array}{l}\text { Tyrosine-protein phosphatase non- } \\
\text { receptor type } 12, \text { PTP-PEST }\end{array}$ & Tyr & nonreceptor & {$[67]$} \\
\hline PTPN14 & $\begin{array}{l}\text { Tyrosine-protein phosphatase non- } \\
\text { receptor type } 14, \mathrm{PEZ}\end{array}$ & Tyr & nonreceptor & {$[68]$} \\
\hline ACP1 & Acid phosphatase of erythrocyte, LMW-PTP & Tyr & nonreceptor & {$[69,70]$} \\
\hline PTPRJ & $\begin{array}{c}\text { Receptor-type tyrosine-protein } \\
\text { phosphatase eta (R-PTP-eta), DEP1 }\end{array}$ & Tyr & Receptor & [71] \\
\hline PTPRM & $\begin{array}{c}\text { Receptor-type tyrosine-protein } \\
\text { phosphatase mu (RPTP mu) }\end{array}$ & Tyr & Receptor & {$[72-74]$} \\
\hline PTPRT & $\begin{array}{l}\text { Receptor-type tyrosine-protein } \\
\text { phosphatase T (R-PTP-T) }\end{array}$ & Tyr & Receptor & {$[75]$} \\
\hline PTPRU & $\begin{array}{l}\text { Receptor-type tyrosine-protein } \\
\text { phosphatase U (R-PTP-U) }\end{array}$ & Tyr & Receptor & {$[76,77]$} \\
\hline PTPRK & $\begin{array}{l}\text { Receptor-type tyrosine-protein } \\
\text { phosphatase kappa }\end{array}$ & Tyr & Receptor & {$[78,79]$} \\
\hline PTPRF & $\begin{array}{c}\text { Receptor-type tyrosine-protein } \\
\text { phosphatase F, LAR }\end{array}$ & Tyr & Receptor & [80-82] \\
\hline PPP2CA & $\begin{array}{l}\text { Serine/threonine-protein phosphatase } 2 \mathrm{~A} \\
\text { catalytic subunit alpha isoform }\end{array}$ & Ser/Thr & nonreceptor & [83-85] \\
\hline
\end{tabular}




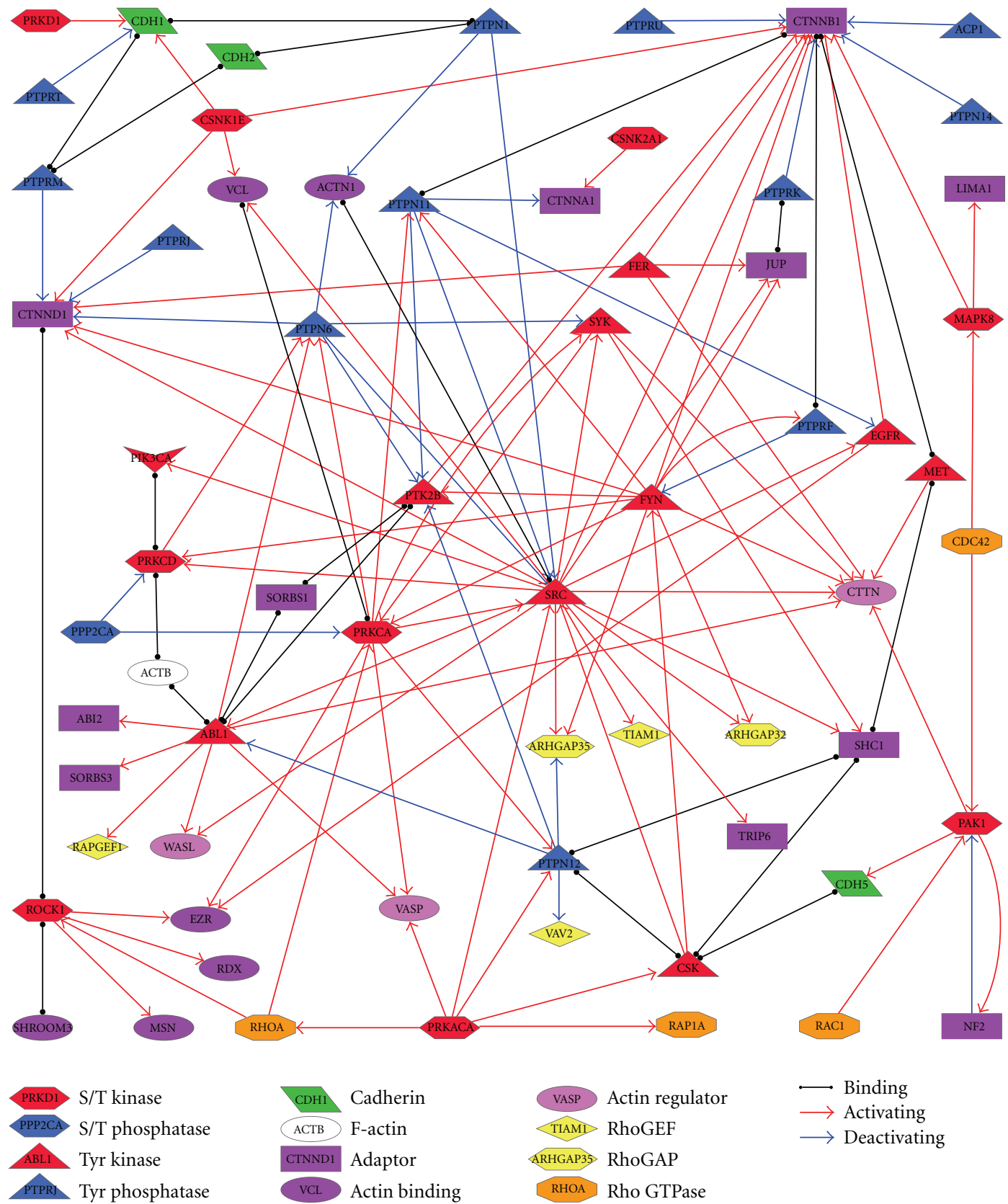

Figure 1: Network of phosphorylation enzymes and targets in the adherens junction.

phosphorylates actin regulators WASP and VASP [143, 144], as well as cadherin-bound adaptor $\delta$-catenin [145] and second layer adaptors Abi2 and Vinexin (SORBS3) [146, 147].

Some AJ proteins have additional functions in the cell, and phosphorylation is also involved in regulating their non-AJ roles [148]. The most notable example is $\beta$-catenin, which plays an important role in the Wnt signaling pathway as a cotranscription factor of TCF/LEF [149]. Whether nonjunctional $\beta$-catenin will reach the nucleus or not depends on whether it is phosphorylated by GSK3 and Casein Kinse I in the "destruction complex" [150]. However, such phosphorylation events taking place outside the context of AJ are beyond the scope of this paper.

For the phosphorylation events occurring within $\mathrm{AJ}$ an important question is how do they affect the target proteins?

\section{Consequences of Phosphorylation on AJ Proteins}

A phosphorylated tyrosine, serine, or threonine residue can affect a protein in three major ways: it can increase the affinity for another protein, it can inhibit a protein-protein 
TABLE 2: Targets of phosphorylation in AJ.

\begin{tabular}{|c|c|c|c|}
\hline Gene symbol & Protein name & Phosphorylated residue & Reference \\
\hline \multicolumn{4}{|c|}{ Transmembrane } \\
\hline $\mathrm{CDH} 1$ & Ecadherin & $S / Y$ & {$[54,86,87]$} \\
\hline PVRL1 & Nectin & $\mathrm{Y}$ & {$[88]$} \\
\hline \multicolumn{4}{|c|}{ Cadherin-or membrane bound } \\
\hline CTNNB1 & $\beta$-catenin & $\mathrm{S} / \mathrm{T} / \mathrm{Y}$ & {$[16,89,90]$} \\
\hline EZR, RDX, MSN & ERM proteins (ezrin/radixin/moesin) & $\mathrm{S} / \mathrm{T} / \mathrm{Y}$ & [91-93] \\
\hline CTNND1 & $\mathrm{p}_{120}-$ catenin & $\mathrm{S} / \mathrm{T} / \mathrm{Y}$ & {$[94,95]$} \\
\hline JUP & Gamma-catenin & $\mathrm{Y}$ & [96] \\
\hline PARD3 & Partitioning defective 3 homolog & $\mathrm{S} / \mathrm{T} / \mathrm{Y}$ & {$[97,98]$} \\
\hline \multicolumn{4}{|c|}{ Secondary adaptors } \\
\hline CTNNA1 & $\alpha$-catenin & $\mathrm{S} / \mathrm{T} / \mathrm{Y}$ & {$[99,100]$} \\
\hline VCL & Vinculin & $\mathrm{S} / \mathrm{Y}$ & {$[101,102]$} \\
\hline LIMA1 & Eplin & S & {$[103]$} \\
\hline VASP & Vasodilator-stimulated phosphoprotein & $\mathrm{S} / \mathrm{T} / \mathrm{Y}$ & [104-106] \\
\hline SHC1 & SHC-transforming protein 1 & $\mathrm{Y}$ & {$[107,108]$} \\
\hline \multicolumn{4}{|c|}{ Actin and actin regulators } \\
\hline ACTN1 & $\alpha$-actinin & $\mathrm{S} / \mathrm{Y}$ & {$[109,110]$} \\
\hline CTTN & Cortactin & $\mathrm{S} / \mathrm{T} / \mathrm{Y}$ & {$[111,112]$} \\
\hline АCTB & F-actin & $\mathrm{S} / \mathrm{Y}$ & [113-115] \\
\hline \multicolumn{4}{|c|}{ GTPASE regulators } \\
\hline $\mathrm{PI} 3 \mathrm{~K}$ & Phospho-inositide-3-kinase & $\mathrm{Y}$ & {$[116]$} \\
\hline RAPGEF1 & Rap guanine nucleotide exchange factor 1 & $\mathrm{Y}$ & [117] \\
\hline ARHGAP35 & rho GAP p190A & $\mathrm{Y}$ & {$[118,119]$} \\
\hline ARHGAP32 & p200RhoGAP & $\mathrm{Y}$ & {$[120,121]$} \\
\hline TIAM1 & T-lymphoma invasion and metastasis-inducing protein 1 & $\mathrm{Y}$ & [122] \\
\hline VAV2 & Vav 2 guanine nucleotide exchange factor & $\mathrm{Y}$ & {$[122,123]$} \\
\hline
\end{tabular}

interaction, or it can activate enzymatic activity. In proteins with an intramolecular interaction, phosphorylation and dephosphorylation can elicit a conformational change in the protein. AJ components provide examples of each type of these outcomes, as detailed henceforth.

(1) Turn "on" Protein-Protein Interaction. Tyrosine phosphorylation can create a docking site for an $\mathrm{SH} 2$ or PTB domain of a partner protein. For example, tyrosine phosphorylation of cadherin creates docking sites for the $\mathrm{SH} 2$ domain of the adaptor SHC1 [151] and the PTB domain of the cell polarity protein Numb [152]. As mentioned earlier, SRC family kinases are inhibited by an intramolecular interaction between a central SH2 domain and a phosphorylated tyrosine at the C-terminus [137].

(2) Turn "off” Protein-Protein Interaction. Examples of interaction inhibition by phosphorylation are also found both between different proteins and intramolecularly: tyrosine phosphorylation of VE-cadherin at certain residues prevents the binding of p120-catenin and $\beta$-catenin [153]; phosphorylation of a threonine residue in the C-terminal actin binding domain of ERM proteins interferes with its interaction with the N-terminal FERM domain, helping to keep the protein in an active open conformation [154].
(3) Turn "on" Enzymatic Activity. Activation of the catalytic activity of tyrosine kinases and phosphatases by tyrosine phosphorylation has already been mentioned above [127]. Another important example is the activation of the motor activity of myosin by the phosphorylation of serine and threonine residues of myosin light chain [155].

We next address the question what are the ramifications of phosphorylation of AJ proteins on AJ structure and dynamics.

\section{Global versus Specific Consequences of Phosphorylation on AJ Structure and Dynamics}

Numerous experiments have been carried out over the years to address the role of $\mathrm{Y}$ and S/T phosphorylation in regulating AJ. Early experiments used broad-spectrum chemical inhibitors of kinases or phosphatases to conclude that phosphorylation negatively impacts cadherin function. For example, inhibition of S/T phosphatases by Okadaic acid or Calyculin-A was reported to lead to complete disassembly of AJ within an hour, and this disruption was attributed to an increase in S/T phosphorylation of $\beta$-catenin [89]. However, Calyculin-A has also been shown to increase actomyosin contractility in cells [156], suggesting that the disruption of 
AJ in the above mentioned study may have been caused by mechanical tension at the junctions exceeding their adhesive strength. Inhibition of tyrosine phosphatases with sodium orthovanadate was reported to lead within minutes to a dramatic increase in phosphotyrosine signals at AJ, followed by the disassembly of AJ [157]. Consistent with the notion that excessive tyrosine phosphorylation in AJ causes their disassembly, cells expressing constitutively active Src kinase lost their AJ, and inhibition of tyrosine kinase activity by the drug tyrphostin was able to restore AJ in the Srctransformed cells [157]. These and similar experiments have led researchers in the late 90 s of the previous century to the general conclusion that phosphorylation is a negative regulator of $\mathrm{AJ}$.

However, in more recent years, there is accumulating evidence for a positive role of phosphorylation in AJ assembly, mainly coming out of loss-of-function experiments of specific kinases. For example, SRC and FYN were found to be essential for the formation of $\mathrm{AJ}$ in mouse keratinocytes [158]. Moreover, SRC activity was shown in vitro to be important for the recruitment of PI3K to AJ and the ability of cells to expand nascent cadherin-adhesive contacts [159]. Along the same lines, ABL1 tyrosine kinase activity was shown to be important for the maintenance of adherens junctions in epithelial cells [37], and S/T phosphorylation of E-cadherin by protein kinase D1 (PRKD1) was found to be associated with increased cellular adhesion and decreased cellular motility in prostate cancer [59].

Hence, the emerging view is that it is not possible to generalize the effect of phosphorylation on AJ. With some phosphorylation events leading to the switching "on" of a protein or interaction and other phosphorylation events, even on the same protein, serving as a switch "off", the effect of phosphorylation on AJ dynamics has to be examined on a residue-by-residue basis. After we delineate the effect of each individual phosphorylation event, we should be able to integrate this information into a single network of interconnected switches and perhaps then we can follow the global effects of a single phosphorylation switch, starting, for example, with hepatocyte growth factor stimulation [160].

\section{Consequences of Specific Phosphorylation Events on AJ, Composition and Dynamics}

We close this paper by giving a few examples of cases in which the consequences of specific phosphorylation events are known. The phosphorylation events presented occur on proteins from each layer of the AJ as well as one cell polarity protein.

(1) Cadherin. Serine phosphorylation of residues S840, S851 and S853 in the C-terminus of human E-cadherin (likely by CSNK1E or PRKD1) increases the binding affinity towards $\beta$-catenin, whereas phosphorylation of S846 is said to inhibit the same interaction [86]. Stronger binding of $\beta$-catenin to E-cadherin is conducive to a stronger AJ structure. Tyrosine phosphorylation of VE-cadherin at two critical tyrosines,
Y658 and Y731, is sufficient to prevent the binding of p120- and $\beta$-catenin, respectively [161]. Phosphorylation by Src of three tyrosines in position 753-755 on human E-cadherin creates a docking site for the E3-ligase Hakai [162]. Ubiquitination of E-cadherin by Hakai leads to internalization of E-cadherin facilitating disassembly of the AJ $[162,163]$.

(2) P120-Catenin. Eight tyrosine residues in the N-terminus of p120-catenin can be phosphorylated by Src [94]. Upon phosphorylation, these sites serve as docking sites for the recruitment of interacting proteins carrying $\mathrm{SH} 2$ domains, such as the tyrosine phosphatase SHP-1 [164]. Under certain conditions tyrosine phosphorylation of p120-catenin was shown to increase its affinity to cadherin, while in other instances such an increase was not observed (reviewed in [95]). The affinity of p120-catenin to cadherin is significant for AJ dynamics because p120-catenin protects cadherin from being internalized [165].

(3) Zyxin. Phosphorylation of S142 of zyxin is thought to result in the release of an intramolecular head-tail interaction [166]. Opening of the protein expose its ACTA repeats that recruit VASP, whose actin polymerization activity (see below) is important for AJ assembly and maintenance. Since zyxinmediated recruitment of VASP has a positive effect on AJ $[167,168]$, it is not surprising that expression of a zyxin phosphomimetic mutant results in ultrastable AJ [166].

(4) VASP (Vasodilator Stimulated Phosphoprotein). As its name suggests, VASP is often found phosphorylated in cells. Three phosphorylation sites on residues S157, S239, and T274 are phosphorylated by PKA and PKG, as well as PKC $[169,170]$ and dephosphorylated by unknown phosphatase/s. The phosphorylation of VASP was shown to reduce its affinity towards actin [171] and essentially turn off its actin bundling and anticapping/elongation activity [171, 172]. VASP-mediated actin elongation is important for the formation of $\mathrm{AJ}$ and for the maintenance of actin structures associated with AJ $[173,174]$. Thus, the consequence of VASP phosphorylation is to negatively regulate AJ assembly and maintenance.

(5) PARD3. In Drosophila epithelial cells the par-3 ortholog Bazooka is confined to AJ as a result of phosphorylation by either apical or basal polarity complexes [4]. At the apical side of cells Bazooka is phosphorylated by aPKC, resulting in its release from the cortex $[175,176]$. In the basolateral membrane Parl kinase phosphorylates Bazooka on unique sites that also lead to its cortical release [4]. Recently, it was shown that the ratio between Par-1 and aPKC determines the position of Bazooka and AJ along the lateral side and a reduction in Par-1 kinase activity leads to a basal shift of AJ followed by folding of the epithelial sheet [177]. 


\section{Conclusions and Outlook}

From the examples presented above, it is clear that phosphorylation switches play a pivotal role in regulating AJ assembly and disassembly dynamics. At the same time it is also clear that our knowledge is only scratching the surface of the phosphorylation network regulating AJ. For the majority of known phosphorylation events in AJ, we know either of a kinase or of a phosphatase involved, but rarely do we know both. Furthermore, while traditional biochemistry techniques have facilitated the characterization of a handful of phosphorylation events on AJ proteins, phosphoproteomic data indicates that the majority of $\mathrm{AJ}$ proteins are phosphorylated on multiple serine/threonine and tyrosine residues [178]. Phosphoproteomics, which utilizes a variety of techniques to label cells, enrich for phosphorylated peptides and identify them using massspectrometry (reviewed in [179-181]), not only highlights the hole in our knowledge but also offers the means to fill it.

Phospho-proteomics offers an unbiased and comprehensive snapshot of phosphorylation events, and several different approaches can be taken to elucidate phosphorylation switches in AJ: during normal assembly and maturation, following a signal for disassembly, or when a certain kinase or phosphatase is activated or missing (e.g., [39, 182-184]). The phospho-proteomic data obtained, especially if it is dynamic, can be used for a systems level analysis of phosphorylation switches in AJ $[185,186]$, but it seems likely to us that before the network can be modeled in a meaningful way more in depth characterization of specific phosphorylation events will be necessary, using cell biological techniques.

While for the discovery and mapping of phosphorylation events in AJ, one wants to be as comprehensive as possible, when it comes to characterizing a particular switch the more specific the tools, the better. One example of a specific tool is phosphorylation site-specific antibodies, such as those recognizing individual phosphorylation events on $\beta$ catenin and p-120-catenin $[187,188]$. Another example are site-specific phospho-mimetic or nonphosphorylatable mutations, such as those successfully applied to the study of the effects of phosphorylation on cortactin, VASP, VEcadherin, zyxin, and paxillin [153, 166, 189-191].

Facing an ever-changing landscape of forces and signaling cues, a cell must respond rapidly by adjusting the strength of its AJs according to need. For this it relies on continuous turnover and assembly of core AJ components. Phosphorylation is particularly suitable for regulating the balance between assembly and disassembly as it is rapid and affects the AJ proteins directly. Feedback loops must guarantee a combination of phosphorylated residues at AJ that matches the requirements for a given condition. Experiments have shown that when it comes to phosphorylation both "all on" and "all off" treatments are deleterious to AJ. The challenge now is to elucidate the mechanisms by which the cell maintains a "just right" level of phosphorylation in AJ. While phosphorylation is probably the most prominent regulatory switch controlling cell adhesion, other switches, such as GTPases, lipids and proteases, do exist [192]. A future challenge, therefore, will be to integrate the phosphorylation switch network with the other regulatory switches to facilitate a true understanding of how different signaling pathways and force regulate $\mathrm{AJ}$ dynamics.

\section{Acknowledgment}

This paper was made possible by an NRF fellowship awarded to R. Zaidel-Bar by the Singapore National Research Foundation.

\section{References}

[1] K. J. Green, S. Getsios, S. Troyanovsky, and L. M. Godsel, "Intercellular junction assembly, dynamics, and homeostasis," Cold Spring Harbor Perspectives in Biology, vol. 2, no. 2, p. a000125, 2010.

[2] M. Takeichi, "Cadherin cell adhesion receptors as a morphogenetic regulator," Science, vol. 251, no. 5000, pp. 1451-1455, 1991.

[3] B. Baum and M. Georgiou, "Dynamics of adherens junctions in epithelial establishment, maintenance, and remodeling," Journal of Cell Biology, vol. 192, no. 6, pp. 907-917, 2011.

[4] D. St Johnston and B. Sanson, "Epithelial polarity and morphogenesis," Current Opinion in Cell Biology, vol. 23, no. 5, pp. 540-546, 2011.

[5] S. Yonemura, Y. Wada, T. Watanabe, A. Nagafuchi, and M. Shibata, " $\alpha$-Catenin as a tension transducer that induces adherens junction development," Nature Cell Biology, vol. 12, no. 6, pp. 533-542, 2010.

[6] T. Lecuit, "Adhesion remodeling underlying tissue morphogenesis," Trends in Cell Biology, vol. 15, no. 1, pp. 34-42, 2005.

[7] T. J. C. Harris, "Adherens junction assembly and function in the Drosophila embryo," International Review of Cell and Molecular Biology, vol. 293, pp. 45-83, 2012.

[8] A. M. Lynch and J. Hardin, "The assembly and maintenance of epithelial junctions in C. Elegans," Frontiers in Bioscience, vol. 14, no. 4, pp. 1414-1432, 2009.

[9] U. H. Frixen, J. Behrens, M. Sachs et al., "E-cadherinmediated cell-cell adhesion prevents invasiveness of human carcinoma cells," Journal of Cell Biology, vol. 113, no. 1, pp. 173-185, 1991.

[10] J. Yoshino, T. Monkawa, M. Tsuji, M. Inukai, H. Itoh, and M. Hayashi, "Snail1 is involved in the renal epithelial-mesenchymal transition," Biochemical and Biophysical Research Communications, vol. 362, no. 1, pp. 63-68, 2007.

[11] R. S. B. Clark, H. Bayir, and L. W. Jenkins, "Posttranslational protein modifications," Critical Care Medicine, vol. 33, no. 12, pp. S407-S409, 2005.

[12] S. Roura, S. Miravet, J. Piedra, A. García De Herreros, and M. Duñachl, "Regulation of E-cadherin/catenin association by tyrosine phosphorylation," Journal of Biological Chemistry, vol. 274, no. 51, pp. 36734-36740, 1999.

[13] R. Michalides, T. Volberg, and B. Geiger, "Augmentation of adherens junction formation in mesenchymal cells by coexpression of N-CAM or short-term stimulation of tyrosinephosphorylation," Cell Adhesion and Communication, vol. 2, no. 6, pp. 481-490, 1994.

[14] V. G. Brunton, I. R. J. MacPherson, and M. C. Frame, "Cell adhesion receptors, tyrosine kinases and actin modulators: a complex three-way circuitry," Biochimica et Biophysica Acta, vol. 1692, no. 2-3, pp. 121-144, 2004. 
[15] J. M. Daniel and A. B. Reynolds, "Tyrosine phosphorylation and cadherin/catenin function," BioEssays, vol. 19, no. 10, pp. 883-891, 1997.

[16] J. Lilien and J. Balsamo, "The regulation of cadherinmediated adhesion by tyrosine phosphorylation/dephosphorylation of $\beta$-catenin," Current Opinion in Cell Biology, vol. 17, no. 5, pp. 459-465, 2005.

[17] T. J. C. Harris and M. Peifer, "Decisions, decisions: $\beta$-catenin chooses between adhesion and transcription," Trends in Cell Biology, vol. 15, no. 5, pp. 234-237, 2005.

[18] M.-H. Park, D.-J. Kim, S.-T. You et al., "Phosphorylation of $\beta$-catenin at serine 663 regulates its transcriptional activity," Biochemical and Biophysical Research Communications, vol. 419, no. 3, pp. 543-549, 2012.

[19] J. Balsamo, T. Leung, H. Ernst, M. K. B. Zanin, S. Hoffman, and J. Lilien, "Regulated binding of a PTP1B-like phosphatase to N-cadherin: control of cadherin-mediated adhesion by dephosphorylation of $\beta$-catenin," Journal of Cell Biology, vol. 134, no. 3, pp. 801-813, 1996.

[20] S. Tsukita, K. Oishi, T. Akiyama, Y. Yamanashi, T. Yamamoto, and S. Tsukita, "Specific proto-oncogenic tyrosine kinases of src family are enriched in cell-to-cell adherens junctions where the level of tyrosine phosphorylation is elevated," Journal of Cell Biology, vol. 113, no. 4, pp. 867-879, 1991.

[21] A. L. Smith, M. R. Dohn, M. V. Brown, and A. B. Reynolds, "Association of Rho-associated protein kinase 1 with Ecadherin complexes is mediated by p120-catenin," Molecular Biology of the Cell, vol. 23, no. 1, pp. 99-110, 2012.

[22] J. Jiang, D. Dean, R. C. Burghardt, and A. R. Parrish, "Disruption of cadherin/catenin expression, localization, and interactions during $\mathrm{HgCl} 2$-induced nephrotoxicity," Toxicological Sciences, vol. 80, no. 1, pp. 170-182, 2004.

[23] N. P. Y. Lee and C. Y. Cheng, "Protein kinases and adherens junction dynamics in the seminiferous epithelium of the rat testis," Journal of Cellular Physiology, vol. 202, no. 2, pp. 344360, 2005.

[24] U. Baumeister, R. Funke, K. Ebnet, H. Vorschmitt, S. Koch, and D. Vestweber, "Association of Csk to VE-cadherin and inhibition of cell proliferation," EMBO Journal, vol. 24, no. 9, pp. 1686-1695, 2005.

[25] P. Sheth, A. Seth, K. J. Atkinson et al., "Acetaldehyde dissociates the PTP1B-E-cadherin- $\beta$-catenin complex in Caco- 2 cell monolayers by a phosphorylation-dependent mechanism," Biochemical Journal, vol. 402, no. 2, pp. 291-300, 2007.

[26] S. P. S. Monga, W. M. Mars, P. Pediaditakis et al., "Hepatocyte growth factor induces Wnt-independent nuclear translocation of $\beta$-catenin after Met- $\beta$-catenin dissociation in hepatocytes," Cancer Research, vol. 62, no. 7, pp. 2064-2071, 2002.

[27] B. Aicher, M. M. Lerch, T. Müller, J. Schilling, and A. Ullrich, "Cellular redistribution of protein tyrosine phosphatases LAR and PTP $\sigma$ by inducible proteolytic processing," Journal of Cell Biology, vol. 138, no. 3, pp. 681-696, 1997.

[28] W. H. Ziegler, U. Tigges, A. Zieseniss, and B. M. Jockusch, "A lipid-regulated docking site on vinculin for protein kinase C," Journal of Biological Chemistry, vol. 277, no. 9, pp. 73967404, 2002.

[29] T. Nishimura and M. Takeichi, "Shroom3-mediated recruitment of Rho kinases to the apical cell junctions regulates epithelial and neuroepithelial planar remodeling," Development, vol. 135, no. 8, pp. 1493-1502, 2008.

[30] M. Shindo, H. Wada, M. Kaido et al., "Dual function of Src in the maintenance of adherens junctions during tracheal epithelial morphogenesis," Development, vol. 135, no. 7, pp. 1355-1364, 2008.

[31] D. W. Owens, G. W. McLean, A. W. Wyke et al., "The catalytic activity of the Src family kinases is required to disrupt cadherin-dependent cell-cell contacts," Molecular Biology of the Cell, vol. 11, no. 1, pp. 51-64, 2000.

[32] H. Jin, B. Garmy-Susini, C. J. Avraamides, K. Stoletov, R. L. Klemke, and J. A. Varner, "A PKA-Csk-pp60Src signaling pathway regulates the switch between endothelial cell invasion and cell-cell adhesion during vascular sprouting," Blood, vol. 116, no. 25, pp. 5773-5783, 2010.

[33] W. Rengifo-Cam, A. Konishi, N. Morishita et al., "Csk defines the ability of integrin-mediated cell adhesion and migration in human colon cancer cells: implication for a potential role in cancer metastasis," Oncogene, vol. 23, no. 1, pp. 289-297, 2004.

[34] J. Piedra, S. Miravet, J. Castaño et al., "p120 cateninassociated Fer and Fyn tyrosine kinases regulate $\beta$-catenin Tyr-142 phosphorylation and $\beta$-catenin- $\alpha$-catenin interaction," Molecular and Cellular Biology, vol. 23, no. 7, pp. 22872297, 2003.

[35] R. Y. J. Huang, S. M. Wang, C. Y. Hsieh, and J. C. Wu, "Lysophosphatidic acid induces ovarian cancer cell dispersal by activating Fyn kinase associated with p120-catenin," International Journal of Cancer, vol. 123, no. 4, pp. 801-809, 2008.

[36] K. L. Hsu, H. J. Fan, Y. C. Chen et al., "Protein kinase C-Fyn kinase cascade mediates the oleic acid-induced disassembly of neonatal rat cardiomyocyte adherens junctions," International Journal of Biochemistry and Cell Biology, vol. 41, no. 7, pp. 1536-1546, 2009.

[37] N. L. Zandy, M. Playford, and A. M. Pendergast, "Abl tyrosine kinases regulate cell- cell adhesion through Rho GTPases," Proceedings of the National Academy of Sciences of the United States of America, vol. 104, no. 45, pp. 17686-17691, 2007.

[38] E. E. Grevengoed, J. J. Loureiro, T. L. Jesse, and M. Peifer, "Abelson kinase regulates epithelial morphogenesis in Drosophila," Journal of Cell Biology, vol. 155, no. 7, pp. 11851197, 2001.

[39] R. M. Larive, S. Urbach, J. Poncet et al., "Phosphoproteomic analysis of Syk kinase signaling in human cancer cells reveals its role in cell-cell adhesion," Oncogene, vol. 28, no. 24, pp. 2337-2347, 2009.

[40] X. Zhang, U. Shrikhande, B. M. Alicie, Q. Zhou, and R. L. Geahlen, "Role of the protein tyrosine kinase Syk in regulating cell-cell adhesion and motility in breast cancer cells," Molecular Cancer Research, vol. 7, no. 5, pp. 634-644, 2009.

[41] J. D. Van Buul, E. C. Anthony, M. Fernandez-Borja, K. Burridge, and P. L. Hordijk, "Proline-rich tyrosine kinase 2 (Pyk2) mediates vascular endothelial-cadherin-based cellcell adhesion by regulating $\beta$-catenin tyrosine phosphorylation," Journal of Biological Chemistry, vol. 280, no. 22, pp. 21129-21136, 2005.

[42] F. De Amicis, M. Lanzino, A. Kisslinger et al., "Loss of proline-rich tyrosine kinase 2 function induces spreading and motility of epithelial prostate cells," Journal of Cellular Physiology, vol. 209, no. 1, pp. 74-80, 2006.

[43] R. J. Cain, B. Vanhaesebroeck, and A. J. Ridley, “The PI3K $\mathrm{p} 110 \alpha$ isoform regulates endothelial adherens junctions via Pyk2 and Rac1," Journal of Cell Biology, vol. 188, no. 6, pp. 863-876, 2010. 
[44] R. Rosato, J. M. Veltmaat, J. Groffen, and N. Heisterkamp, "Involvement of the tyrosine kinase Fer in cell adhesion," Molecular and Cellular Biology, vol. 18, no. 10, pp. 5762-5770, 1998.

[45] H. Hoschuetzky, H. Aberle, and R. Kemler, " $\beta$-Catenin mediates the interaction of the cadherin-catenin complex with epidermal growth factor receptor," Journal of Cell Biology, vol. 127, no. 5, pp. 1375-1380, 1994.

[46] G. Davies, W. G. Jiang, and M. D. Mason, "HGF/SF modifies the interaction between its receptor c-Met, and the E-cadherin/catenin complex in prostate cancer cells," International Journal of Molecular Medicine, vol. 7, no. 4, pp. 385-388, 2001.

[47] C. L. Williams and J. D. Noti, "Reduced expression of Wnt1 and E-cadherin, and diminished beta-catenin stability in MCF-7 breast cancer cells that overexpress protein kinase Calpha," International Journal of Oncology, vol. 19, no. 6, pp. 1227-1233, 2001.

[48] M. J. Boucher, P. Laprise, and N. Rivard, "Cyclic AMPdependent protein kinase A negatively modulates adherens junction integrity and differentiation of intestinal epithelial cells," Journal of Cellular Physiology, vol. 202, no. 1, pp. 178190, 2005.

[49] F. Leve, W. De Souza, and J. A. Morgado-Díaz, "A cross-link between protein kinase A and Rho-family GTPases signaling mediates cell-cell adhesion and actin cytoskeleton organization in epithelial cancer cells," Journal of Pharmacology and Experimental Therapeutics, vol. 327, no. 3, pp. 777-788, 2008.

[50] K. Taguchi, T. Ishiuchi, and M. Takeichi, "Mechanosensitive EPLIN-dependent remodeling of adherens junctions regulates epithelial reshaping," Journal of Cell Biology, vol. 194, no. 4, pp. 643-656, 2011.

[51] C. L. Chen and H. C. Chen, "Functional suppression of Ecadherin by protein kinase C $\delta$," Journal of Cell Science, vol. 122, no. 4, pp. 513-523, 2009.

[52] R. Singh, P. Lei, and S. T. Andreadis, "PKC- $\delta$ binds to Ecadherin and mediates EGF-induced cell scattering," Experimental Cell Research, vol. 315, no. 17, pp. 2899-2913, 2009.

[53] D. Casagolda, B. Del Valle-Pérez, G. Valls et al., "A p120catenin-CK1 $1 \varepsilon$ complex regulates Wnt signaling," Journal of Cell Science, vol. 123, no. 15, pp. 2621-2631, 2010.

[54] H. Lickert, A. Bauer, R. Kemler, and J. Stappert, "Casein kinase II phosphorylation of E-cadherin increases Ecadherin/ $\beta$ - catenin interaction and strengthens cell-cell adhesion," Journal of Biological Chemistry, vol. 275, no. 7, pp. 5090-5095, 2000.

[55] C. Pirraglia, J. Walters, and M. M. Myat, "Pak1 control of Ecadherin endocytosis regulates salivary gland lumen size and shape," Development, vol. 137, no. 24, pp. 4177-4189, 2010.

[56] S. Elloul, O. Vaksman, H. T. Stavnes, C. G. Trope, B. Davidson, and R. Reich, "Mesenchymal-to-epithelial transition determinants as characteristics of ovarian carcinoma effusions," Clinical and Experimental Metastasis, vol. 27, no. 3, pp. 161-172, 2010.

[57] H. He, A. Shulkes, and G. S. Baldwin, "PAK1 interacts with $\beta$-catenin and is required for the regulation of the $\beta$-catenin signalling pathway by gastrins," Biochimica et Biophysica Acta, vol. 1783, no. 10, pp. 1943-1954, 2008.

[58] M. H. Lee, P. Koria, J. Qu, and S. T. Andreadis, "JNK phosphorylates $\beta$-catenin and regulates adherens junctions," FASEB Journal, vol. 23, no. 11, pp. 3874-3883, 2009.

[59] M. Jaggi, P. S. Rao, D. J. Smith et al., "E-cadherin phosphorylation by protein kinase D1/protein kinase $\mathrm{C} \mu$ is associated with altered cellular aggregation and motility in prostate cancer," Cancer Research, vol. 65, no. 2, pp. 483-492, 2005.

[60] A. Suzuki, T. Yamanaka, T. Hirose et al., "Atypical protein kinase $\mathrm{C}$ is involved in the evolutionarily conserved PAR protein complex and plays a critical role in establishing epitheliaspecific junctional structures," Journal of Cell Biology, vol. 152, no. 6, pp. 1183-1196, 2001.

[61] M. Elbert, D. Cohen, and A. Müsch, "PAR1b promotes cellcell adhesion and inhibits dishevelled-mediated transformation of Madin-Darby canine kidney cells," Molecular Biology of the Cell, vol. 17, no. 8, pp. 3345-3355, 2006.

[62] J. Balsamo, C. Arregui, T. Leung, and J. Lilien, "The nonreceptor protein tyrosine phosphatase PTP1B binds to the cytoplasmic domain of $\mathrm{N}$-cadherin and regulates the cadherin-actin linkage," Journal of Cell Biology, vol. 143, no. 2, pp. 523-532, 1998.

[63] P. Pathre, C. Arregui, T. Wampler et al., "PTP1B regulates neurite extension mediated by cell-cell and cell-matrix adhesion molecules," Journal of Neuroscience Research, vol. 63, no. 2, pp. 143-150, 2001.

[64] M. V. Hernández, D. P. Wehrendt, and C. O. Arregui, “The protein tyrosine phosphatase PTP1B is required for efficient delivery of N-cadherin to the cell surface," Molecular Biology of the Cell, vol. 21, no. 8, pp. 1387-1397, 2010.

[65] J. Schnekenburger, J. Mayerle, B. Krüger et al., "Protein tyrosine phosphatase $\kappa$ and SHP-1 are involved in the regulation of cell-cell contacts at adherens junctions in the exocrine pancreas," Gut, vol. 54, no. 10, pp. 1445-1455, 2005.

[66] J. A. Ukropec, M. K. Hollinger, S. M. Salva, and M. J. Woolkalis, "SHP2 association with VE-cadherin complexes in human endothelial cells is regulated by thrombin," Journal of Biological Chemistry, vol. 275, no. 8, pp. 5983-5986, 2000.

[67] R. Espejo, W. Rengifo-Cam, M. D. Schaller, B. M. Evers, and S. K. Sastry, "PTP-PEST controls motility, adherens junction assembly, and Rho GTPase activity in colon cancer cells," American Journal of Physiology, vol. 299, no. 2, pp. C454C463, 2010.

[68] C. Wadham, J. R. Gamble, M. A. Vadas, and Y. KhewGoodall, "The protein tyrosine phosphatase Pez is a major phosphatase of adherens junctions and dephosphorylates $\beta$ catenin," Molecular Biology of the Cell, vol. 14, no. 6, pp. 2520-2529, 2003.

[69] M. L. Taddei, P. Chiarugi, P. Cirri et al., “ $\beta$-catenin interacts with low-molecular-weight protein tyrosine phosphatase leading to cadherin-mediated cell-cell adhesion increase," Cancer Research, vol. 62, no. 22, pp. 6489-6499, 2002.

[70] W. B. Fang, R. C. Ireton, G. Zhuang, T. Takahashi, A. Reynolds, and J. Chen, "Overexpression of EPHA2 receptor destabilizes adherens junctions via a RhoA-dependent mechanism," Journal of Cell Science, vol. 121, no. 3, pp. 358-368, 2008.

[71] L. J. Holsinger, K. Ward, B. Duffield, J. Zachwieja, and B. Jallal, "The transmembrane receptor protein tyrosine phosphatase DEP1 interacts with p120ctn," Oncogene, vol. 21, no. 46, pp. 7067-7076, 2002.

[72] G. C. M. Zondag, A. B. Reynolds, and W. H. Moolenaar, "Receptor protein-tyrosine phosphatase RPTP $\mu$ binds to and dephosphorylates the catenin p120(ctn)," Journal of Biological Chemistry, vol. 275, no. 15, pp. 11264-11269, 2000.

[73] S. M. Brady-Kalnay, T. Mourton, J. P. Nixon et al., "Dynamic interactions of $\mathrm{PTP} \mu$ with multiple cadherins in vivo," Journal of Cell Biology, vol. 141, no. 1, pp. 287-296, 1998. 
[74] S. Hiscox and W. G. Jiang, "Association of PTP $\mu$ with catenins in cancer cells: a possible role for E-cadherin," International Journal of Oncology, vol. 13, no. 5, pp. 1077-1080, 1998.

[75] J. A. Besco, R. Hooft van Huijsduijnen, A. Frostholm, and A. Rotter, "Intracellular substrates of brain-enriched receptor protein tyrosine phosphatase rho (RPTP $\rho /$ PTPRT)," Brain Research, vol. 1116, no. 1, pp. 50-57, 2006.

[76] H. X. Yan, Y. Q. He, H. Dong et al., "Physical and functional interaction between receptor-like protein tyrosine phosphatase PCP-2 and $\beta$-catenin," Biochemistry, vol. 41, no. 52, pp. 15854-15860, 2002.

[77] H. X. Yan, W. Yang, R. Zhang et al., "Protein-tyrosine phosphatase PCP-2 inhibits $\beta$-catenin signaling and increases E-cadherin-dependent cell adhesion," Journal of Biological Chemistry, vol. 281, no. 22, pp. 15423-15433, 2006.

[78] L. Novellino, A. De Filippo, P. Deho et al., "PTPRK negatively regulates transcriptional activity of wild type and mutated oncogenic $\beta$-catenin and affects membrane distribution of $\beta$-catenin/E-cadherin complexes in cancer cells," Cellular Signalling, vol. 20, no. 5, pp. 872-883, 2008.

[79] C. Wang, Z. Li, Z. Yang et al., "The effect of receptor protein tyrosine phosphatase kappa on the change of cell adhesion and proliferation induced by $\mathrm{N}$-acetylglucosaminyltransferase V," Journal of Cellular Biochemistry, vol. 109, no. 1, pp. 113-123, 2010.

[80] R. M. Kypta, H. Su, and L. F. Reichardt, "Association between a transmembrane protein tyrosine phosphatase and the cadherin-catenin complex," Journal of Cell Biology, vol. 134, no. 6, pp. 1519-1529, 1996.

[81] J. R. Symons, C. M. Levea, and R. A. Mooney, "Expression of the leucocyte common antigen-related (LAR) tyrosine phosphatase is regulated by cell density through functional E-cadherin complexes," Biochemical Journal, vol. 365, no. 2, pp. 513-519, 2002.

[82] T. Müller, A. Choidas, E. Reichmann, and A. Ullrich, "Phosphorylation and free pool of $\beta$-catenin are regulated by tyrosine kinases and tyrosine phosphatases during epithelial cell migration," Journal of Biological Chemistry, vol. 274, no. 15, pp. 10173-10183, 1999.

[83] M. Nita-Lazar, I. Rebustini, J. Walker, and M. A. Kukuruzinska, "Hypoglycosylated E-cadherin promotes the assembly of tight junctions through the recruitment of PP2A to adherens junctions," Experimental Cell Research, vol. 316, no. 11, pp. 1871-1884, 2010.

[84] K. Suzuki and K. Takahashi, "Induction of E-cadherin endocytosis by loss of protein phosphatase 2A expression in human breast cancers," Biochemical and Biophysical Research Communications, vol. 349, no. 1, pp. 255-260, 2006.

[85] J. Götz, A. Probst, C. Mistl, R. M. Nitsch, and E. Ehler, "Distinct role of protein phosphatase $2 \mathrm{~A}$ subunit $\mathrm{C} \alpha$ in the regulation of E-cadherin and $\beta$-catenin during development," Mechanisms of Development, vol. 93, no. 1-2, pp. 8393, 2000.

[86] S. Dupre-Crochet, A. Figueroa, C. Hogan et al., "Casein kinase 1 is a novel negative regulator of E-cadherin-based cell-cell contacts," Molecular and Cellular Biology, vol. 27, no. 10, pp. 3804-3816, 2007.

[87] J. Qi, J. Wang, O. Romanyuk, and C. H. Siu, "Involvement of Src family kinases in $\mathrm{N}$-cadherin phosphorylation and $\beta$-catenin dissociation during transendothelial migration of melanoma cells," Molecular Biology of the Cell, vol. 17, no. 3, pp. 1261-1272, 2006.
[88] M. Kikyo, T. Matozaki, A. Kodama, H. Kawabe, H. Nakanishi, and Y. Takai, "Cell-cell adhesion-mediated tyrosine phosphorylation of nectin- $2 \delta$, an immunoglobulin-like cell adhesion molecule at adherens junctions," Oncogene, vol. 19, no. 35, pp. 4022-4028, 2000.

[89] M. Serres, C. Grangeasse, M. Haftek, Y. Durocher, B. Duclos, and D. Schmitt, "Hyperphosphorylation of $\beta$-catenin on serine-threonine residues and loss of cell-cell contacts induced by calyculin A and okadaic acid in human epidermal cells," Experimental Cell Research, vol. 231, no. 1, pp. 163$172,1997$.

[90] H. S. Moon, E. A. Choi, H. Y. Park et al., "Expression and tyrosine phosphorylation of E-cadherin, $\beta$ - and $\gamma$-catenin, and epidermal growth factor receptor in cervical cancer cells," Gynecologic Oncology, vol. 81, no. 3, pp. 355-359, 2001.

[91] L. Heiska and O. Carpén, "Src phosphorylates ezrin at tyrosine 477 and induces a phosphospecific association between ezrin and a kelch-repeat protein family member," Journal of Biological Chemistry, vol. 280, no. 11, pp. 1024410252, 2005.

[92] R. Zhou, X. Cao, C. Watson et al., "Characterization of protein kinase A-mediated phosphorylation of ezrin in gastric parietal cell activation," Journal of Biological Chemistry, vol. 278, no. 37, pp. 35651-35659, 2003.

[93] J. Chen, J. A. Cohn, and L. J. Mandel, “Dephosphorylation of ezrin as an early event in renal microvillar breakdown and anoxic injury," Proceedings of the National Academy of Sciences of the United States of America, vol. 92, no. 16, pp. 7495-7499, 1995.

[94] D. J. Mariner, P. Anastasiadis, H. Keilhack, F. D. Böhmer, J. Wang, and A. B. Reynolds, "Identification of Src phosphorylation sites in the catenin p120 ctn," Journal of Biological Chemistry, vol. 276, no. 30, pp. 28006-28013, 2001.

[95] S. Alemà and A. M. Salvatore, "p120 catenin and phosphorylation: mechanisms and traits of an unresolved issue," Biochimica et Biophysica Acta, vol. 1773, no. 1, pp. 47-58, 2007.

[96] S. Miravet, J. Piedra, J. Castaño et al., "Tyrosine phosphorylation of plakoglobin causes contrary effects on its association with desmosomes and adherens junction components and modulates $\beta$-catenin-mediated transcription," Molecular and Cellular Biology, vol. 23, no. 20, pp. 7391-7402, 2003.

[97] Y. Wang, D. Du, L. Fang et al., "Tyrosine phosphorylated Par3 regulates epithelial tight junction assembly promoted by EGFR signaling," EMBO Journal, vol. 25, no. 21, pp. 50585070, 2006.

[98] A. Traweger, G. Wiggin, L. Taylor, S. A. Tate, P. Metalnikov, and T. Pawson, "Protein phosphatase 1 regulates the phosphorylation state of the polarity scaffold Par-3," Proceedings of the National Academy of Sciences of the United States of America, vol. 105, no. 30, pp. 10402-10407, 2008.

[99] J. Burks and Y. M. Agazie, "Modulation of $\alpha$-catenin Tyr phosphorylation by SHP2 positively effects cell transformation induced by the constitutively active FGFR3," Oncogene, vol. 25, no. 54, pp. 7166-7179, 2006.

[100] H. Ji, J. Wang, H. Nika et al., "EGF-Induced ERK activation promotes CK2-mediated disassociation of $\alpha$-catenin from $\beta$ catenin and transactivation of $\beta$-catenin," Molecular Cell, vol. 36, no. 4, pp. 547-559, 2009.

[101] S. Nakajo, K. Nakaya, and Y. Nakamura, "Phosphorylation of actin-binding proteins by casein kinases 1 and 2," Biochemistry International, vol. 15, no. 2, pp. 321-327, 1987. 
[102] Z. Zhang, G. Izaguirre, S. Y. Lin, H. Y. Lee, E. Schaefer, and B. Haimovich, "The phosphorylation of vinculin on tyrosine residues 100 and 1065, mediated by Src kinases, affects cell spreading," Molecular Biology of the Cell, vol. 15, no. 9, pp. 4234-4247, 2004.

[103] M. Y. Han, H. Kosako, T. Watanabe, and S. Hattori, "Extracellular signal-regulated kinase/mitogen-activated protein kinase regulates actin organization and cell motility by phosphorylating the actin cross-linking protein EPLIN," Molecular and Cellular Biology, vol. 27, no. 23, pp. 8190-8204, 2007.

[104] M. Maruoka, M. Sato, Y. Yuan et al., "Abi-1-bridged tyrosine phosphorylation of VASP by Abelson kinase impairs association of VASP to focal adhesions and regulates leukaemic cell adhesion," Biochemical Journal, vol. 441, no. 3, pp. 889-899, 2012.

[105] D. M. Thomson, M. P. A. Ascione, J. Grange, C. Nelson, and M. D. H. Hansen, "Phosphorylation of VASP by AMPK alters actin binding and occurs at a novel site," Biochemical and Biophysical Research Communications, vol. 414, no. 1, pp. 215-219, 2011.

[106] A. Deguchi, J. W. Soh, H. Li, R. Pamukcu, W. J. Thompson, and I. B. Weinstein, "Vasodilator-stimulated phosphoprotein (VASP) phosphorylation provides a biomarker for the action of exisulind and related agents that activate protein kinase G." Molecular cancer therapeutics, vol. 1, no. 10, pp. 803-809, 2002.

[107] S. F. Walk, M. E. March, and K. S. Ravichandran, "Roles of Lck, Syk and ZAP-70 tyrosine kinases in TCR-mediated phosphorylation of the adapter protein Shc," European Journal of Immunology, vol. 28, no. 8, pp. 2265-2275, 1998.

[108] P. Van Der Geer, S. Wiley, G. D. Gish, and T. Pawson, "The Shc adaptor protein is highly phosphorylated at conserved, twin tyrosine residues (Y239/240) that mediate proteinprotein interactions," Current Biology, vol. 6, no. 11, pp. 1435-1444, 1996.

[109] M. Grønborg, T. Z. Kristiansen, A. Stensballe et al., "A mass spectrometry-based proteomic approach for identification of serine/threonine-phosphorylated proteins by enrichment with phospho-specific antibodies: identification of a novel protein, Frigg, as a protein kinase A substrate," Molecular \& Cellular Proteomics, vol. 1, no. 7, pp. 517-527, 2002.

[110] H. Shao, C. Wu, and A. Wells, "Phosphorylation of $\alpha$ actinin 4 upon epidermal growth factor exposure regulates its interaction with actin," Journal of Biological Chemistry, vol. 285, no. 4, pp. 2591-2600, 2010.

[111] W. Sangrar, Y. Gao, M. Scott, P. Truesdell, and P. A. Greer, "Fer-mediated cortactin phosphorylation is associated with efficient fibroblast migration and is dependent on reactive oxygen species generation during integrin-mediated cell adhesion," Molecular and Cellular Biology, vol. 27, no. 17, pp. 6140-6152, 2007.

[112] A. Grassart, V. Meas-Yedid, A. Dufour, J. C. Olivo-Marin, A. Dautry-Varsat, and N. Sauvonnet, "Pak1 phosphorylation enhances cortactin-N-WASP interaction in clathrincaveolin-independent endocytosis," Traffic, vol. 11, no. 8, pp. 1079-1091, 2010.

[113] S. Van Delft, A. J. Verkleij, and J. Boonstra, "Epidermal growth factor induces serine phosphorylation of actin," FEBS Letters, vol. 357, no. 3, pp. 251-254, 1995.

[114] E. A. Papakonstanti and C. Stournaras, "Association of PI3 kinase with PAK1 leads to actin phosphorylation and cytoskeletal reorganization," Molecular Biology of the Cell, vol. 13, no. 8, pp. 2946-2962, 2002.
[115] X. Liu, S. Shu, M. S. S. Hong, R. L. Levine, and E. D. Korn, "Phosphorylation of actin Tyr-53 inhibits filament nucleation and elongation and destabilizes filaments," Proceedings of the National Academy of Sciences of the United States of America, vol. 103, no. 37, pp. 13694-13699, 2006.

[116] A. Arcaro, M. Aubert, M. E. Espinosa del Hierro et al., "Critical role for lipid raft-associated Src kinases in activation of PI3K-Akt signalling," Cellular Signalling, vol. 19, no. 5, pp. 1081-1092, 2007.

[117] A. Mitra and V. Radha, "F-actin-binding domain of c-Abl regulates localized phosphorylation of C3G: role of C3G in cAbl-mediated cell death," Oncogene, vol. 29, no. 32, pp. 45284542, 2010.

[118] R. M. Wolf, J. J. Wilkes, M. V. Chao, and M. D. Resh, "Tyrosine phosphorylation of p190 RhoGAP by Fyn regulates oligodendrocyte differentiation," Journal of Neurobiology, vol. 49, no. 1, pp. 62-78, 2001.

[119] R. W. Roof, M. D. Haskell, B. D. Dukes, N. Sherman, M. Kinter, and S. J. Parsons, "Phosphotyrosine (p-Tyr)dependent and -independent mechanisms of p190 RhoGAPp120 RasGAP interaction: Tyr 1105 of p190, a substrate for c-Src, is the sole p-Tyr mediator of complex formation," Molecular and Cellular Biology, vol. 18, no. 12, pp. 7052-7063, 1998.

[120] S. Taniguchi, H. Liu, T. Nakazawa, K. Yokoyama, T. Tezuka, and T. Yamamoto, "p250GAP, a neural RhoGAP protein, is associated with and phosphorylated by Fyn," Biochemical and Biophysical Research Communications, vol. 306, no. 1, pp. 151-155, 2003.

[121] S. Y. Moon, H. Zang, and Y. Zheng, "Characterization of a brain-specific Rho GTPase-activating protein, p200RhoGAP," Journal of Biological Chemistry, vol. 278, no. 6, pp. 4151-4159, 2003.

[122] J. M. Servitja, M. J. Marinissen, A. Sodhi, X. R. Bustelo, and J. S. Gutkind, "Rac1 function is required for Src-induced transformation: evidence of a role for Tiam1 and Vav2 in Rac activation by Src," Journal of Biological Chemistry, vol. 278, no. 36, pp. 34339-34346, 2003.

[123] S. K. Sastry, Z. Rajfur, B. P. Liu, J. F. Cote, M. L. Tremblay, and K. Burridge, "PTP-PEST couples membrane protrusion and tail retraction via VAV2 and p190RhoGAP," Journal of Biological Chemistry, vol. 281, no. 17, pp. 11627-11636, 2006.

[124] S. R. Hubbard and J. H. Till, "Protein tyrosine kinase structure and function," Annual Review of Biochemistry, vol. 69, pp. 373-398, 2000.

[125] A. W. Stoker, "Protein tyrosine phosphatases and signalling," Journal of Endocrinology, vol. 185, no. 1, pp. 19-33, 2005.

[126] G. C. M. Zondag and W. H. Moolenaar, "Receptor protein tyrosine phosphatases: involvement in cell-cell interaction and signaling," Biochimie, vol. 79, no. 8, pp. 477-483, 1997.

[127] S. Dadke, A. Kusari, and J. Kusari, "Phosphorylation and activation of protein tyrosine phosphatase (PTP) 1B by insulin receptor," Molecular and Cellular Biochemistry, vol. 221, no. 1-2, pp. 147-154, 2001.

[128] K. Fujisawa, A. Fujita, T. Ishizaki, Y. Saito, and S. Narumiya, "Identification of the Rho-binding domain of p160(ROCK), a Rho-associated coiled-coil containing protein kinase," Journal of Biological Chemistry, vol. 271, no. 38, pp. 2302223028, 1996.

[129] W. Lu and B. J. Mayer, "Mechanism of activation of Pak1 kinase by membrane localization," Oncogene, vol. 18, no. 3, pp. 797-806, 1999.

[130] T. Rosenzweig, S. Aga-Mizrachi, A. Bak, and S. R. Sampson, "Src tyrosine kinase regulates insulin-induced activation 
of protein kinase C (PKC) $\delta$ in skeletal muscle," Cellular Signalling, vol. 16, no. 11, pp. 1299-1308, 2004.

[131] K. Yoshida and D. Kufe, "Negative regulation of the SHPTP1 protein tyrosine phosphatase by protein kinase $\mathrm{C} \delta$ in response to DNA damage," Molecular Pharmacology, vol. 60, no. 6, pp. 1431-1438, 2001.

[132] A. K. Somani, J. S. Bignon, G. B. Mills, K. A. Siminovitch, and D. R. Branch, "Src kinase activity is regulated by the SHP-1 protein-tyrosine phosphatase," Journal of Biological Chemistry, vol. 272, no. 34, pp. 21113-21119, 1997.

[133] Y. Obara, K. Labudda, T. J. Dillon, and P. J. S. Stork, "PKA phosphorylation of Src mediates Rap1 activation in NGF and cAMP signaling in PC12 cells," Journal of Cell Science, vol. 117, no. 25, pp. 6085-6094, 2004.

[134] T. Vang, K. M. Torgersen, V. Sundvold et al., "Activation of the COOH-terminal Src kinase (Csk) by cAMP-dependent protein kinase inhibits signaling through the T cell receptor," Journal of Experimental Medicine, vol. 193, no. 4, pp. 497507, 2001.

[135] G. Superti-Furga, S. Fumagalli, M. Koegl, S. A. Courtneidge, and G. Draetta, "Csk inhibition of c-Src activity requires both the $\mathrm{SH} 2$ and $\mathrm{SH} 3$ domains of Src," EMBO Journal, vol. 12, no. 7, pp. 2625-2634, 1993.

[136] R. W. McLachlan and A. S. Yap, "Not so simple: the complexity of phosphotyrosine signaling at cadherin adhesive contacts," Journal of Molecular Medicine, vol. 85, no. 6, pp. 545-554, 2007.

[137] B. Nagar, O. Hantschel, M. A. Young et al., "Structural basis for the autoinhibition of c-Abl tyrosine kinase," Cell, vol. 112, no. 6, pp. 859-871, 2003.

[138] T. Y. El Sayegh, P. D. Arora, L. Fan et al., "Phosphorylation of N-cadherin-associated cortactin by Fer kinase regulates $\mathrm{N}$-cadherin mobility and intercellular adhesion strength," Molecular Biology of the Cell, vol. 16, no. 12, pp. 5514-5527, 2005.

[139] N. L. Zandy and A. M. Pendergast, "Abl tyrosine kinases modulate cadherin-dependent adhesion upstream and downstream of Rho family GTPases," Cell Cycle, vol. 7, no. 4, pp. 444-448, 2008.

[140] C. K. Joo, H. S. Kim, J. Y. Park, Y. Seomun, M. J. Son, and J. T. Kim, "Ligand release-independent transactivation of epidermal growth factor receptor by transforming growth factor- $\beta$ involves multiple signaling pathways," Oncogene, vol. 27, no. 5, pp. 614-628, 2008.

[141] T. Watanabe, K. Sato, and K. Kaibuchi, "Cadherin-mediated intercellular adhesion and signaling cascades involving small GTPases," Cold Spring Harbor Perspectives in Biology, vol. 1, no. 3, p. a003020, 2009.

[142] V. M. M. Braga and A. S. Yap, "The challenges of abundance: epithelial junctions and small GTPase signalling," Current Opinion in Cell Biology, vol. 17, no. 5, pp. 466-474, 2005.

[143] E. A. Burton, T. N. Oliver, and A. M. Pendergast, "Abl kinases regulate actin comet tail elongation via an N-WASPdependent pathway," Molecular and Cellular Biology, vol. 25, no. 20, pp. 8834-8843, 2005.

[144] M. Martin, S. M. Ahern-Djamali, F. M. Hoffmann, and W. M. Saxton, "Abl tyrosine kinase and its substrate Ena/VASP have functional interactions with kinesin-1," Molecular Biology of the Cell, vol. 16, no. 9, pp. 4225-4230, 2005.

[145] Q. Lu, N. K. Mukhopadhyay, J. D. Griffin, M. Paredes, M. Medina, and K. S. Kosik, "Brain armadillo protein $\delta$-catenin interacts with Abl tyrosine kinase and modulates cellular morphogenesis in response to growth factors," Journal of Neuroscience Research, vol. 67, no. 5, pp. 618-624, 2002.
[146] Z. Dai and A. M. Pendergast, "Abi-2, a novel SH3-containing protein interacts with the c-Abl tyrosine kinase and modulates c-Abl transforming activity," Genes and Development, vol. 9, no. 21, pp. 2569-2582, 1995.

[147] M. Mitsushima, H. Takahashi, T. Shishido, K. Ueda, and N. Kioka, "Abl kinase interacts with and phosphorylates vinexin,” FEBS Letters, vol. 580, no. 17, pp. 4288-4295, 2006.

[148] P. D. McCrea, D. Gu, and M. S. Balda, "Junctional music that the nucleus hears: cell-cell contact signaling and the modulation of gene activity," Cold Spring Harbor Perspectives in Biology, vol. 1, no. 4, p. a002923, 2009.

[149] F. H. Brembeck, M. Rosário, and W. Birchmeier, "Balancing cell adhesion and Wnt signaling, the key role of $\beta$-catenin," Current Opinion in Genetics and Development, vol. 16, no. 1, pp. 51-59, 2006.

[150] W. J. Nelson and R. Nusse, "Convergence of Wnt, $\beta$-Catenin, and Cadherin pathways," Science, vol. 303, no. 5663, pp. 1483-1487, 2004.

[151] Y. Xu and G. Carpenter, "Identification of cadherin tyrosine residues that are phosphorylated and mediate Shc association," Journal of Cellular Biochemistry, vol. 75, no. 2, pp. 264271, 1999.

[152] Z. Wang, S. Sandiford, C. Wu, and S. S. C. Li, "Numb regulates cell-cell adhesion and polarity in response to tyrosine kinase signalling," EMBO Journal, vol. 28, no. 16, pp. 2360-2373, 2009.

[153] M. D. Potter, S. Barbero, and D. A. Cheresh, "Tyrosine phosphorylation of VE-cadherin prevents binding of p120- and $\beta$-catenin and maintains the cellular mesenchymal state," Journal of Biological Chemistry, vol. 280, no. 36, pp. 3190631912, 2005.

[154] S. Yonemura, T. Matsui, S. Tsukita, and S. Tsukita, "Rho-dependent and -indenpendent activation mechanisms of ezrin/radixin/moesin proteins: an essential role for polyphosphoinositides in vivo," Journal of Cell Science, vol. 115, no. 12, pp. 2569-2580, 2002.

[155] M. Amano, M. Ito, K. Kimura et al., "Phosphorylation and activation of myosin by Rho-associated kinase (Rhokinase)," Journal of Biological Chemistry, vol. 271, no. 34, pp. 20246-20249, 1996.

[156] J. H. Henson, S. E. Kolnik, C. A. Fried et al., "Actinbased centripetal flow: phosphatase inhibition by calyculinA alters flow pattern, actin organization, and actomyosin distribution," Cell Motility and the Cytoskeleton, vol. 56, no. 4, pp. 252-266, 2003.

[157] T. Volberg, Y. Zick, R. Dror et al., "The effect of tyrosine-specific protein phosphorylation on the assembly of adherens-type junctions," EMBO Journal, vol. 11, no. 5, pp. 1733-1742, 1992.

[158] E. Calautti, S. Cabodi, P. L. Stein, M. Hatzfeld, N. Kedersha, and G. P. Dotto, "Tyrosine phosphorylation and Src family kinases control keratinocyte cell-cell adhesion," Journal of Cell Biology, vol. 141, no. 6, pp. 1449-1465, 1998.

[159] J. H. Pang, A. Kraemer, S. J. Stehbens, M. C. Frame, and A. S. Yap, "Recruitment of phosphoinositide 3-kinase defines a positive contribution of tyrosine kinase signaling to Ecadherin function," Journal of Biological Chemistry, vol. 280, no. 4, pp. 3043-3050, 2005.

[160] S. Shibamoto, M. Hayakawa, K. Takeuchi et al., "Tyrosine phosphorylation of $\beta$-catenin and plakoglobin enhanced by hepatocyte growth factor and epidermal growth factor in human carcinoma cells," Cell Adhesion and Communication, vol. 1, no. 4, pp. 295-305, 1994. 
[161] K. Hatanaka, M. Simons, and M. Murakami, "Phosphorylation of VE-cadherin controls endothelial phenotypes via p120-catenin coupling and Racl activation," American Journal of Physiology, vol. 300, no. 1, pp. H162-H172, 2011.

[162] S. Pece and J. S. Gutkind, "E-cadherin and Hakai: signalling, remodeling or destruction?" Nature Cell Biology, vol. 4, no. 4, pp. E72-E74, 2002.

[163] Y. Fujita, G. Krause, M. Scheffner et al., "Hakai, a c-Cbllike protein, ubiquitinates and induces endocytosis of the Ecadherin complex," Nature Cell Biology, vol. 4, no. 3, pp. 222231, 2002.

[164] H. Keilhack, U. Hellman, J. Van Hengel, F. Van Roy, J. Godovac-Zimmermann, and F. D. Böhmer, "The proteintyrosine phosphatase SHP-1 binds to and dephosphorylates p120 catenin," Journal of Biological Chemistry, vol. 275, no. 34, pp. 26376-26384, 2000.

[165] Y. Fukumoto, Y. Shintani, A. B. Reynolds, K. R. Johnson, and M. J. Wheelock, "The regulatory or phosphorylation domain of p120 catenin controls E-cadherin dynamics at the plasma membrane," Experimental Cell Research, vol. 314, no. 1, pp. 52-67, 2008.

[166] G. S. Call, J. Y. Chung, J. A. Davis et al., “Zyxin phosphorylation at serine 142 modulates the zyxin head-tail interaction to alter cell-cell adhesion," Biochemical and Biophysical Research Communications, vol. 404, no. 3, pp. 780-784, 2011.

[167] T. N. Nguyen, A. Uemura, W. Shih, and S. Yamada, "Zyxinmediated actin assembly is required for efficient wound closure," Journal of Biological Chemistry, vol. 285, no. 46, pp. 35439-35445, 2010.

[168] M. D. H. Hansen and M. C. Beckerle, "Opposing roles of Zyxin/LPP ACTA repeats and the LIM domain region in cellcell adhesion," Journal of Biological Chemistry, vol. 281, no. 23, pp. 16178-16188, 2006.

[169] E. Butt, K. Abel, M. Krieger et al., "cAMP- and cGMPdependent protein kinase phosphorylation sites of the focal adhesion vasodilator-stimulated phosphoprotein (VASP) in vitro and in intact human platelets," Journal of Biological Chemistry, vol. 269, no. 20, pp. 14509-14517, 1994.

[170] K. Chitaley, L. Chen, A. Galler, U. Walter, G. Daum, and A. W. Clowes, "Vasodilator-stimulated phosphoprotein is a substrate for protein kinase C," FEBS Letters, vol. 556, no. 13, pp. 211-215, 2004.

[171] B. Harbeck, S. Hüttelmaier, K. Schlüter, B. M. Jockusch, and S. Illenberger, "Phosphorylation of the vasodilatorstimulated phosphoprotein regulates its interaction witn actin," Journal of Biological Chemistry, vol. 275, no. 40, pp. 30817-30825, 2000.

[172] M. Barzik, T. I. Kotova, H. N. Higgs et al., "Ena/VASP proteins enhance actin polymerization in the presence of barbed end capping proteins," Journal of Biological Chemistry, vol. 280, no. 31, pp. 28653-28662, 2005.

[173] V. Vasioukhin, C. Bauer, M. Yin, and E. Fuchs, "Directed actin polymerization is the driving force for epithelial cellcell adhesion," Cell, vol. 100, no. 2, pp. 209-219, 2000.

[174] J. A. Scott, A. M. Shewan, N. R. Den Elzen, J. J. Loureiro, F. B. Gertler, and A. S. Yap, "Ena/VASP proteins can regulate distinct modes of actin organization at cadherin-adhesive contacts," Molecular Biology of the Cell, vol. 17, no. 3, pp. 1085-1095, 2006.

[175] E. Morais-de-Sá, V. Mirouse, and D. St Johnston, “aPKC phosphorylation of bazooka defines the apical/lateral border in Drosophila epithelial cells," Cell, vol. 141, no. 3, pp. 509523, 2010.

[176] R. F. Walther and F. Pichaud, "Crumbs/DaPKC-dependent apical exclusion of bazooka promotes photoreceptor polarity remodeling," Current Biology, vol. 20, no. 12, pp. 1065-1074, 2010.

[177] Y.-C. Wang, Z. Khan, M. Kaschube, and E. F. Wieschaus, "Differential positioning of adherens junctions is associated with initiation of epithelial folding," Nature, vol. 484, no. 7394, pp. 390-393, 2012.

[178] P. V. Hornbeck, I. Chabra, J. M. Kornhauser, E. Skrzypek, and B. Zhang, "PhosphoSite: a bioinformatics resource dedicated to physiological protein phosphorylation," Proteomics, vol. 4, no. 6, pp. 1551-1561, 2004.

[179] A. M. E. Jones and T. S. Nühse, "Phosphoproteomics using iTRAQ," Methods in Molecular Biology, vol. 779, pp. 287-302, 2011.

[180] B. Eyrich, A. Sickmann, and R. P. Zahedi, "Catch me if you can: mass spectrometry-based phosphoproteomics and quantification strategies," Proteomics, vol. 11, no. 4, pp. 554570, 2011.

[181] H. Imamura, N. Yachie, R. Saito, Y. Ishihama, and M. Tomita, "Towards the systematic discovery of signal transduction networks using phosphorylation dynamics data," BMC Bioinformatics, vol. 11, article 232, 2010.

[182] I. Martinez-Ferrando, R. Chaerkady, J. Zhong et al., "Identification of targets of c-Src tyrosine kinase by chemical complementation and phosphoproteomics," Molecular and Cellular Proteomics. In press.

[183] M. Hilger, T. Bonaldi, F. Gnad, and M. Mann, "Systemswide analysis of a phosphatase knock-down by quantitative proteomics and phosphoproteomics," Molecular and Cellular Proteomics, vol. 8, no. 8, pp. 1908-1920, 2009.

[184] P. H. Huang, A. Mukasa, R. Bonavia et al., "Quantitative analysis of EGFRvIII cellular signaling networks reveals a combinatorial therapeutic strategy for glioblastoma," Proceedings of the National Academy of Sciences of the United States of America, vol. 104, no. 31, pp. 12867-12872, 2007.

[185] H. Kozuka-Hata, S. Tasaki, and M. Oyama, "Phosphoproteomics-based systems analysis of signal transduction networks," Frontiers in Physiology, vol. 2, no. 113, 2011.

[186] A. Derouiche, C. Cousin, and I. Mijakovic, "Protein phosphorylation from the perspectiveof systems biology," Current Opinion in Biotechnology. In press.

[187] E. Sadot, M. Conacci-Sorrell, J. Zhurinsky et al., "Regulation of S33/S37 phosphorylated $\beta$-catenin in normal and transformed cells," Journal of Cell Science, vol. 115, no. 13, pp. 2771-2780, 2002.

[188] M. V. Brown, P. E. Burnett, M. F. Denning, and A. B. Reynolds, "PDGF receptor activation induces p120-catenin phosphorylation at serine 879 via a PKC $\alpha$-dependent pathway," Experimental Cell Research, vol. 315, no. 1, pp. 39-49, 2009.

[189] G. Ren, F. M. Helwani, S. Verma, R. W. McLachlan, S. A. Weed, and A. S. Yap, "Cortactin is a functional target of E-cadherin-activated Src family kinases in MCF7 epithelial monolayers," Journal of Biological Chemistry, vol. 284, no. 28, pp. 18913-18922, 2009.

[190] P. M. Benz, C. Blume, S. Seifert et al., "Differential VASP phosphorylation controls remodeling of the actin cytoskeleton," Journal of Cell Science, vol. 122, no. 21, pp. 3954-3965, 2009. 
[191] R. Zaidel-Bar, R. Milo, Z. Kam, and B. Geiger, "A paxillin tyrosine phosphorylation switch regulates the assembly and form of cell-matrix adhesions," Journal of Cell Science, vol. 120, no. 1, pp. 137-148, 2007.

[192] R. Zaidel-Bar and B. Geiger, "The switchable integrin adhesome," Journal of Cell Science, vol. 123, no. 9, pp. 13851388, 2010. 

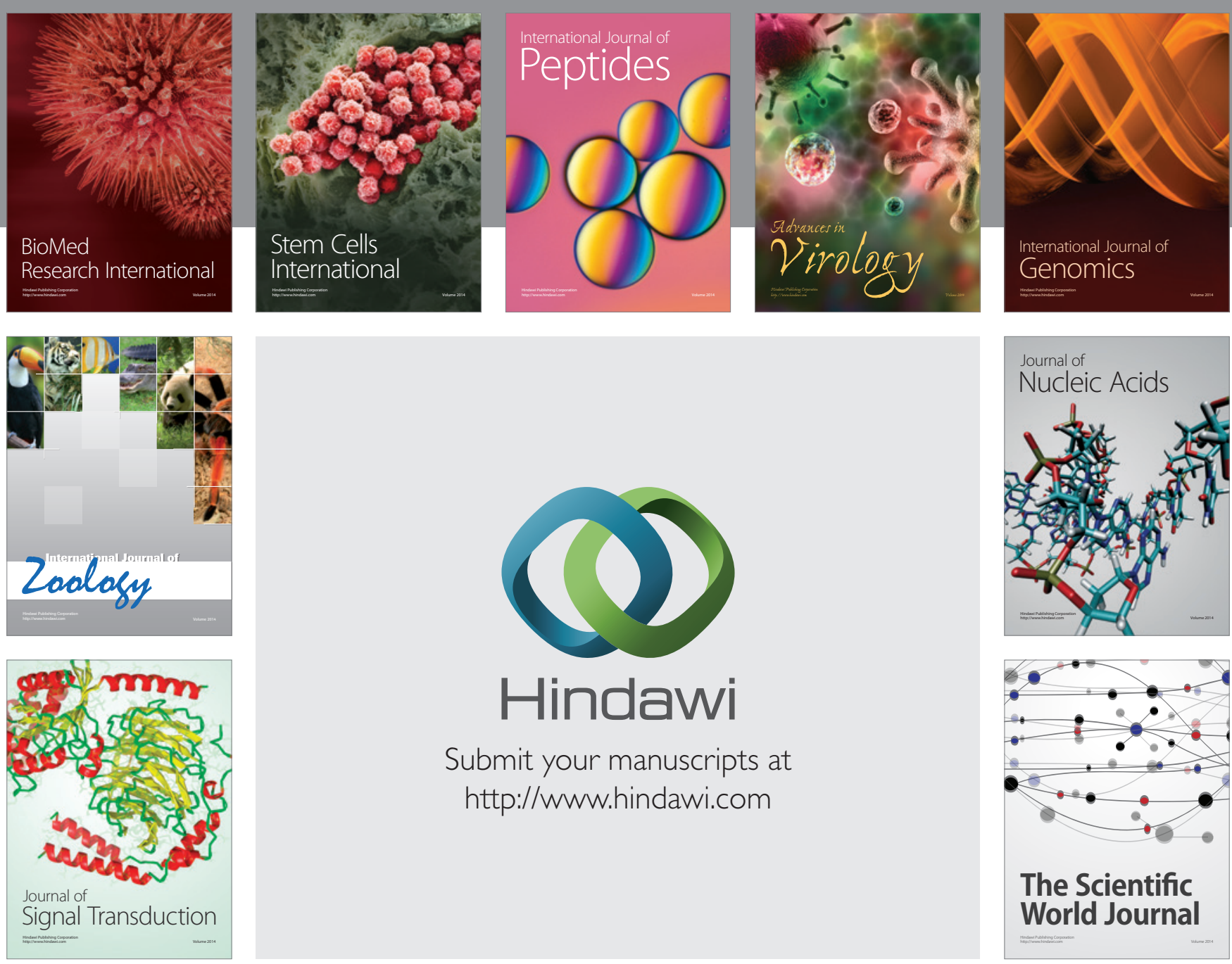

Submit your manuscripts at

http://www.hindawi.com
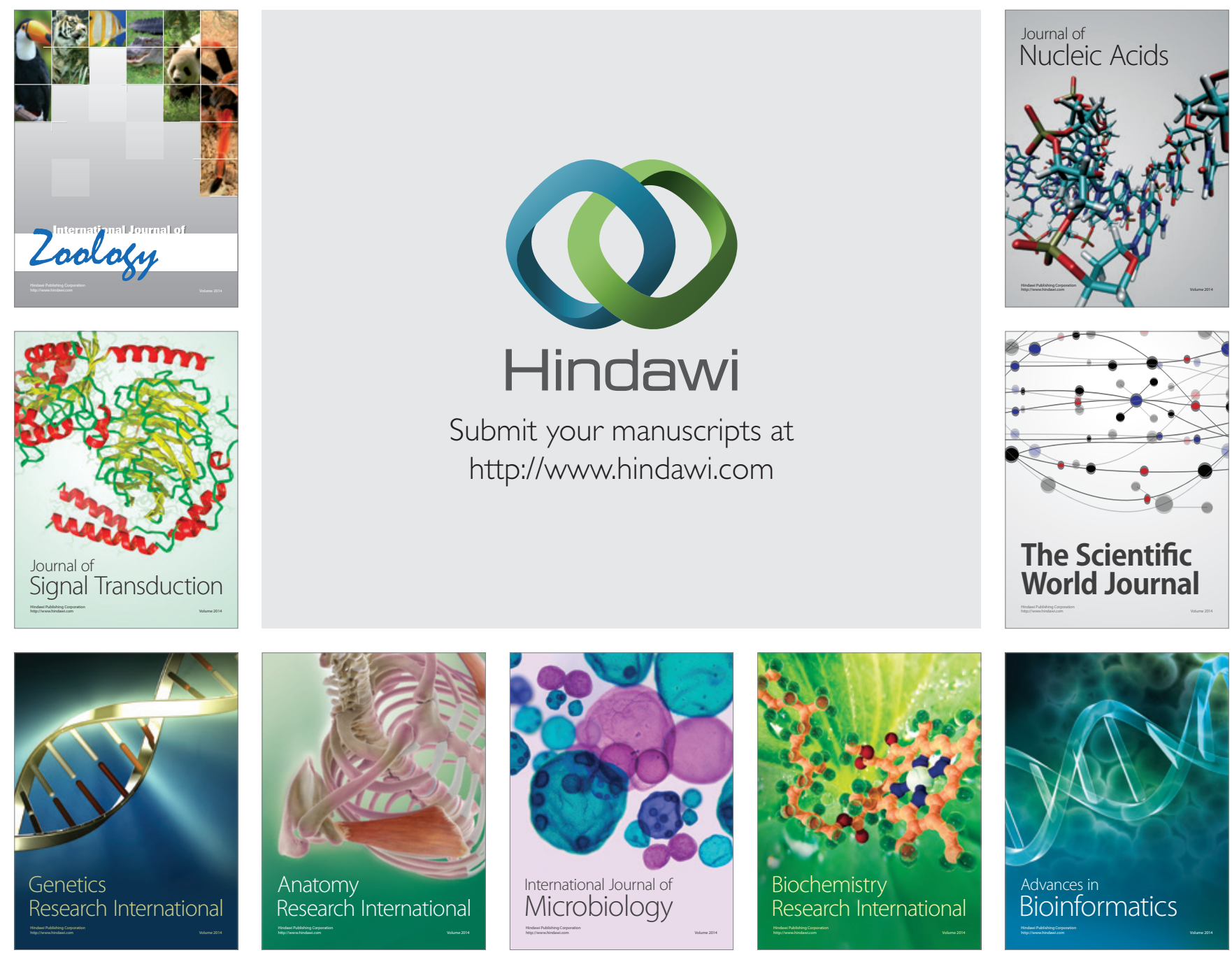

The Scientific World Journal
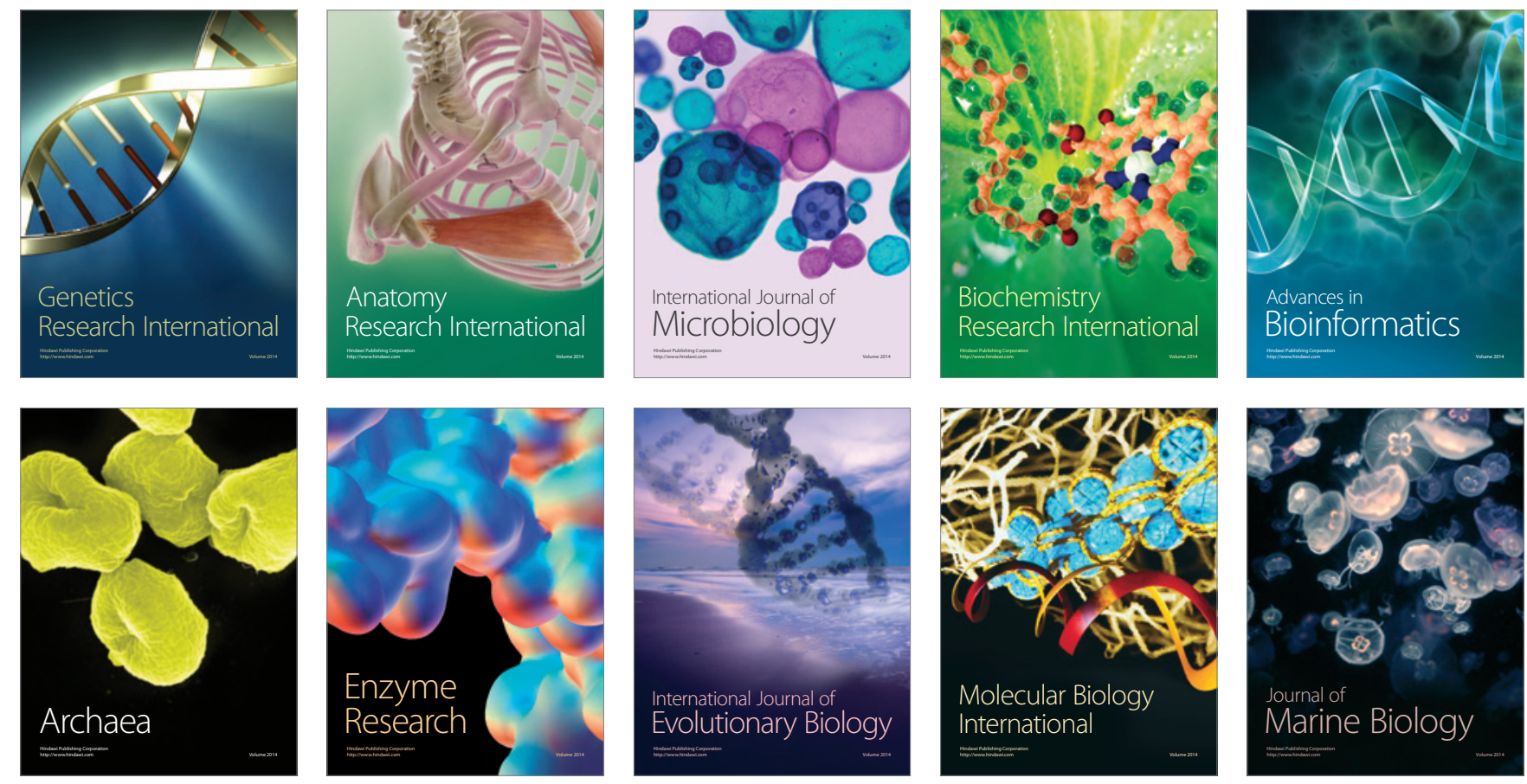